\title{
Dysphagia lusoria presenting as epigastric pain
}

\author{
Hoda Daher, ${ }^{1}$ Samer Al Hadidi ${ }^{2}$
}

${ }^{1}$ Internal Medicine, Hurley Medical Center, Flint, Michigan, USA

${ }^{2}$ Department of Internal Medicine, Hurley Medical Center/Michigan State University, Flint, Michigan, USA

\section{Correspondence to} Dr Samer Al Hadidi, salhadi1@hurleymc.com

Accepted 27 November 2017
To cite: Daher H, Al Hadidi S. BMJ Case Rep Published Online First: [please include Day Month Year]. doi:10.1136/bcr-2017223687

\section{DESCRIPTION}

A 36-year-old African-American woman with medical history of systemic lupus erythematosus, lupus nephritis, protein $S$ deficiency and recurrent deep venous thrombosis presented to outpatient clinic complaining of epigastric pain associated with nausea, vomiting and unintentional weight loss. Esophagogastroduodenoscopy (EGD) was performed; however, mucosal tear was noted following severe retching. Subsequently, the procedure was terminated. EGD was significant for distal oesophageal obstruction. CT of the chest with contrast was significant for pneumomediastinum. Moreover it demonstrated an aberrant right subclavian artery compressing on the posterior part of the oesophagus (figure 1). The patient was diagnosed with dysphagia lusoria. This patient's symptoms were moderate and managed with dietary modifications. Thus, surgical intervention was not recommended. There was no further progression of symptoms at 1 -year follow-up.

Dysphagia lusoria is a condition that occurs as a result of vascular compression of the oesophagus by an aberrant right subclavian artery; the brachiocephalic trunk is absent, and four large arteries arise from the arch of the aorta: the right common carotid artery, the left common carotid artery, the left subclavian artery, and the final one with the most distal left-sided origin, the right subclavian

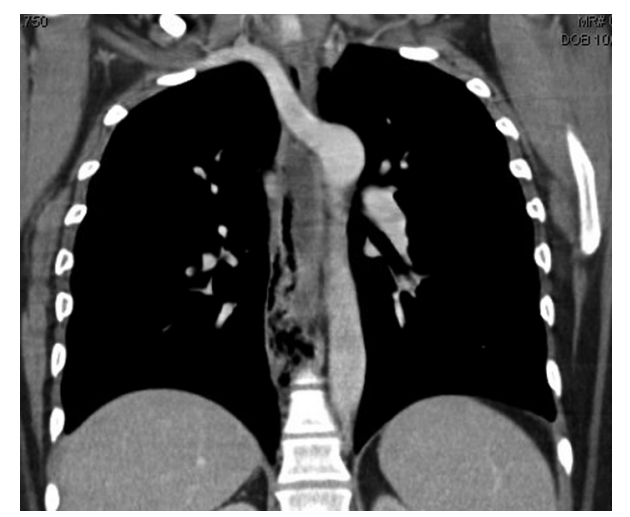

Figure 1 Aberrant right subclavian artery compressing on the posterior part of the oesophagus. artery, also called the arteria lusoria. This vessel travels to the right arm, crossing the middle line of the body and usually passing behind the oesophagus, resulting in oesophageal and tracheal compression. ${ }^{1}$

Dysphagia lusoria was first described in the medical literature in 1794 by David Bayford, ${ }^{2}$ and has a prevalence of up to $1.8 \% .^{3}$ Of the affected patients 30\%-40\% are symptomatic. The mean age of symptoms onset is 50 years, with dysphagia being the most common symptom (71.2\%), followed by dyspnoea and retrosternal pain. ${ }^{1}$

\section{Learning points}

Dysphagia lusoria occurs as a result of tracheooesophageal compression by an aberrant subclavian artery, which is a rare anatomical variant of the origin of the right subclavian artery.

- Dysphagia lusoria is often asymptomatic, but around $30 \%$ of patients may complain of dysphagia, dyspnoea and retrosternal pain.

- High index of suspicion is the key for diagnosis during work-up for dysphagia (barium fluoroscopy and EGD), dyspnoea and retrosternal pain with $\mathrm{CT}$.

Contributors HD reviewed the case and wrote the manuscript. $\mathrm{SAH}$ reviewed the manuscript and related literature and approved the final version of submission.

Competing interests None declared.

Patient consent Guardian consent obtained.

Provenance and peer review Not commissioned; externally peer reviewed.

(c) BMJ Publishing Group Ltd (unless otherwise stated in the text of the article) 2017. All rights reserved. No commercial use is permitted unless otherwise expressly granted.

\section{REFERENCES}

1 Polguj M, Chrzanowski Ł, Kasprzak JD, et al. The aberrant right subclavian artery (arteria lusoria): the morphological and clinical aspects of one of the most important variations-a systematic study of 141 reports. ScientificWorldJournal 2014;2014:1-6.

2 Asherson N. David Bayford. His syndrome and sign of dysphagia lusoria. Ann R Coll Surg Eng/ 1979;61:63-7.

3 Dandelooy J, Coveliers JPM, Van Schil PEY, et al. Dysphagia lusoria. Can Med Assoc J 2009;181:498. 
Copyright 2017 BMJ Publishing Group. All rights reserved. For permission to reuse any of this content visit http://group.bmj.com/group/rights-licensing/permissions.

BMJ Case Report Fellows may re-use this article for personal use and teaching without any further permission.

Become a Fellow of BMJ Case Reports today and you can:

- Submit as many cases as you like

- Enjoy fast sympathetic peer review and rapid publication of accepted articles

Access all the published articles

- Re-use any of the published material for personal use and teaching without further permission

For information on Institutional Fellowships contact consortiasales@bmjgroup.com

Visit casereports.bmj.com for more articles like this and to become a Fellow 